\title{
Elemental and Amino Acid Status of Cucurbita Pepo Seed
}

\author{
Adedokun Adetoro Afusat, Afolabi Olumide, Afolabi Fatai \\ Department Of Basic Sciences, School Of Basic Studies, Osun State Polytechic, Iree \\ Department Of Science Laboratory Technology, Faculty of Science, Osun State Polytechic, Iree \\ Department of Applied Sciences, Faculty of Science, Osun State Polytechic, Iree
}

\begin{abstract}
The element and amino acid status of cucurbita Pepo seed were determined using standard method of analyses. The elemental composition of cucurbita Pepo seed showed sodium with $344.10 \mathrm{mg} / 100 \mathrm{~g}$ to be the highest followed by calcium with $214.60 \pm 0.020 \mathrm{mg} 100 \mathrm{~g}$. Other elements determined were magnesium $12.60 \pm 10 \mathrm{mg} / 100 \mathrm{~g}$, potassium $94.80 \pm 0.20 \mathrm{~g} / 100 \mathrm{~g}$, Iron, $14.20 \pm 0.50 \mathrm{mg} / \mathrm{kg}$; copper $4.10 \pm 0.2 \mathrm{mgkg}$ and manganese $4.64 \pm 0.04 \mathrm{mg} / \mathrm{kg}$. The vitamin content $(\mathrm{mg} / 100 \mathrm{~g})$ of seed was found to be $14.663 \pm 0.001$. The amino acid profile of Cucurbita pepo seed $(\mathrm{g} / 16 \mathrm{gN})$ was found to range from $0.940 \pm 0.001$ to $4.12 \pm 0.002$ for cystein and leucine respectively. The result of the analysis reveals that the seed is edible and sill be utilized industrially in the formulation of food, food supplement and cosmetics.
\end{abstract}

Keyword: Cucurbita pepo, elemental analysis, amino acid, supplement, cosmetics.

\section{Introduction}

Cucurbita pepo is perhaps the most variable species for fruit characteristics in the plant kingdom (Duchesne, 1786; Naudin, 1856). It is native to North America, where it has been cultivated for at least 100,000 years (smith, 1997), but was introduced to Europe only about 500 years ago (Whitaker, 1997) this species includes edible fruited forms, known as pumpkin and squash, and small fruited, often bitter, non-edible forms known as gourds.

Cucurbita pepo is among the economically most important vegetable crops worldwide and is today widely cultivated as food and for decorative purpose in all warm and temperate regions of the globe.

The seeds have been used in traditional medicine as an antihelmintic and taenicide, demulcent, diuretic and tonic. A tea made from the seeds has been used as a remedy for hypertrophy of the prostate gland.

The production of pharmaceutical product from the pumpkin seeds obviously demands the use of botanically defined species, so as to obtain reproducible form from a chemical point of view. The biologically active compounds include $3 \%$ to $5 \%$ oil, proteins $(31 \%-51 \%)$. The carbohydrate content is between $6 \%$ and $10 \%$ while that of mineral is between $4 \%$ and $5 \%$. Main fatty acid are linoleum acid (43\%-55\%) and oleic acid $(27 \%-38 \%)$. The aims of this work is to investigate the elemental composition and the amino acid profile of the Cucurbita pepo seed in rote to provide an attractive source in replacing the already existing element and amino acid sources which could not meet up with demand of the increasing population.

\section{Material And Method}

Seed sample were obtained from commercial market IIa Orangun, Osun State.

The seeds were de-hulled washed, drained and sun-dried for about two weeks for proper drying and to aid easy removal of the shell. The seeds were sun-dried again for 5 days before grinding into fine powder using laboratory mortar and pestle. The sample was then sieved through a mesh of aperture $2 \mathrm{~mm}$ and later in air tight polythene bag ready for analysis.

\section{Methodology}

Mineral contents $(\mathrm{Ca}, \mathrm{Mg} . \mathrm{Fe}, \mathrm{Cu}$, and $\mathrm{Mn})$ were determined on aliquots of the solution of ash by established Atomic Absorption Spectrophotometer while Na and $\mathrm{K}$ were determined by flame photometer. The amino acid analysis was done by ion exchange chromatography IEC (FAO/WHO1991). .The ascorbic acid content was determined spectrophotometrically using the modified methods of Adyogmus and cetin (2002)

Results;

\section{Results And Discussion}

Table 1 : Elemental Composition of Cucurbita pepo seed

\begin{tabular}{|l|l|l|l|l|l|l|l|l|}
\hline Parameter & $\mathrm{Na}$ & $\mathrm{K}$ & $\mathrm{Ca}$ & $\mathrm{Mg}$ & $\mathrm{Fe}$ & $\mathrm{Cu}$ & $\mathrm{Mn}$ \\
\hline Value \pm S.D & 344.10 & 94.80 & 214.60 & 12.60 & 14.20 & 4.10 & 4.64 & Vit. C \\
& \pm 0.10 & \pm 0.20 & \pm 0.20 & \pm 0.10 & \pm 0.20 & \pm 0.20 & \pm 0.04 & \pm 0.003 \\
\hline
\end{tabular}

Note $=\mathrm{mg} / 100 \mathrm{~g} * *=\mathrm{mg} / \mathrm{kg}$ 
Table 2: Amino acid profile of Cucurbita pepo seed $(\mathrm{g} / \mathrm{kgN})$

\begin{tabular}{|c|c|c|c|c|c|c|c|c|c|}
\hline \multicolumn{6}{|c|}{ Note. Levc- Leucine } & \multicolumn{4}{|c|}{ Isolev- Isoleucine } \\
\hline Parameter & Leuc. & $\begin{array}{l}\text { Isole } \\
\text { u. }\end{array}$ & Cyst. & Lys. & Meh & Tryt. & His. & Arg. & Phenyl \\
\hline $\begin{array}{l}\text { Value } \\
\pm \text { S.D }\end{array}$ & $\begin{array}{l}4.124 \\
\pm 0.02\end{array}$ & $\begin{array}{l}3.140 \\
\pm 0.00 \\
1\end{array}$ & $\begin{array}{l}0.940 \\
\pm 0.00 \\
1\end{array}$ & $\begin{array}{l}1.680 \\
\pm 0.002\end{array}$ & $\begin{array}{l}2.0 \\
\pm 0.005\end{array}$ & $\begin{array}{l}1.060 \\
\pm 0.00 \\
2\end{array}$ & $\begin{array}{l}1.227 \\
\pm 0.00 \\
1\end{array}$ & $\begin{array}{l}2.174 \\
\pm 0.010\end{array}$ & $\begin{array}{l}2.740 \\
\pm 0.050\end{array}$ \\
\hline
\end{tabular}

\section{Cyst-Cystein}

Meth-Methionene

His-Histidine

Pheny-Phenlalanine

\author{
Lys-Lysine \\ Trypt-Tryptohan \\ Ars-Arsine
}

\section{Discussion}

Table 1 Showed the elemental Composition of Cucurbita pepo. Sodium (Na) was found to be the abundant mineral with $344.10 \pm 0.1 \mathrm{mg} / 100 \mathrm{~g}$. Copper $(\mathrm{Cu})$ with $4.10 \pm 0.20 \mathrm{mg} / \mathrm{kg}$ the least. The 344 . $10 \pm 0.01 \mathrm{mg} / 100 \mathrm{~g}$ obtained for sodium $(\mathrm{Na})$ was found higher than $236.20 \pm 2.4 \mathrm{mg} / 100 \mathrm{~g}$ of Pentaeclethra Macrophylla seed reported by Odoemelam (2005). The $94.80 \pm 20 \mathrm{mg} / 100 \mathrm{~g}$ obtained for potassium (K) was found higher than $8.2 \mathrm{mg} / 100 \mathrm{~g}$ obtained from cashew nut kernel (Akintokun et al 2008). The $214.60 \pm 20 \mathrm{mg} / 100 \mathrm{~g}$ obtaind for calcium $(\mathrm{Ca})$ was lower than $415.38 \pm 3.14 / 100 \mathrm{~g}$ reported for sesamum indicum L seed (Nzioku et al, 2009). Calcium is of benefit in blood clotting, metabolic process and also in bone formation (Aremu et al.2006).

The Magnesium which is useful in activating many enzymatic systems and maintain the electrical potential many in nerves (Ferao et al, 1987) was found to be $12.60 \pm 0.10 \mathrm{mg} / 100 \mathrm{~g}$ this value is lower than $71.05 \pm 0.02 \mathrm{mg} / 100 \mathrm{~g}$ for C. pulcherrima seed (Oyeleke, 2009b) but higher than $3.60 \pm \mathrm{mg} / 100 \mathrm{~g}$ of palm kernel oil (Akin hanni et al 2009). The $14.20 \pm 0.50 \mathrm{mg} / 100 \mathrm{~g}$ obtained here for iron $(\mathrm{Fe})$ is lower than $225.000 \mathrm{Ng} / \mathrm{g}$ of Cucurbita Pepo L. seed and 206.32ppm of Monodora myristica seeds.(Idouraine et al,1996). It is the major component of and chlorophyll responsible for greenish coloration of the plants and enhance phosynthesis to take place. Iron is also of the hemoglobin and myoglobin molecules involved in oxygen transport to and within the cells. (Burabai et al 2009). The $4.10 \pm 0.20 \mathrm{mg}$ obtained here for copper $(\mathrm{Cu})$ is higher than $0.30 \mathrm{mg} / \mathrm{kg}$ of pumpkin seed. Copper $(\mathrm{Cu})$ is good for health but very high can cause healhth problem such as live and kidney damage (ATSDR,2004) The upper tolerable intake level of copper for children (1-3year) and male/female (1970years). Is 1 and $10 \mathrm{mg} / \mathrm{g}$ respectively (Institute of Medicine, 2003).

The $4.64 \pm 0.04 \mathrm{mg} / \mathrm{kg}$ obtained for manganese $(\mathrm{Mn})$ is lower than $11.53 \mathrm{ppm}$ in Mondora myristical seeds and $117.00 \mathrm{ug} / \mathrm{g}$ Cucrbita pepo L. seeds reported by Burubai et al, (2009) and Indouraine et al, (1960) respectively.

The Vitamin C (Ascorbic acid) content in $\mathrm{mg} / 100 \mathrm{~g}$ of the seed to be $14.63 \pm 0.003 \mathrm{mg} / 100 \mathrm{~g}$, this value is low compared to $83.33 \mathrm{mg} / 100$ and $260 \mathrm{mg} / 100 \mathrm{~g}$ reported for fresh pawpaw and guava seed respectively 9Ashaye et al,2005) the value obtained in this study is also lowet than the vitamin $\mathrm{C}$ recommended daily allowance (RDA) foe adult daily which is $36.6 \mathrm{mg} / 100 \mathrm{~g}$ (USDA,2004).

Table 2 showed the Amino acid profile of Cucurbita seed oil. The essential amino acid in Cucurbita pepo seed were leucine $4.124 \pm 0.002 / 16 \mathrm{gN}$. Isoleucine Lryophan $(1.060 \pm 0.0002 \mathrm{gN})$ Meethionine $(2.075 \pm 0.005 \mathrm{~g} / 16 \mathrm{gN})(1.227 \pm 0.001 \mathrm{~g} / 16 \mathrm{gN})$. The non-essental amino acids in Cucurbita pepo were cystine $(0.940 \pm 0.001 \mathrm{~g} / 16 \mathrm{gN})$ and arginine $(2.174 \pm 0.010 \mathrm{~g} / 16 \mathrm{~N})$. Cucurbita pepo seed oil exhibits lower amino acid content compared to Lophira lanceolata seed oil that have its essential amino acids value to be Leucine $(.5 .29 \mathrm{~g} / 16 \mathrm{gN})$ Lysine $(4.39 / 16 \mathrm{gN})$ and isoleucine $(3.16 \mathrm{~g} / 16 \mathrm{~N})$. Other amino compared well with FAO reference protein reported by Uaboi et al., (2008) with cystine showing the lowest value $0.940 \mathrm{~g} / 16 \mathrm{gN}$ protein.

\section{Conclusion}

From elemental and amino acids composition of seed analyzed Cucurbita Pepo seed flour can therefore be used as food fortification in human food.

\section{References}

[1]. Akintokun., Herrick R.J and Egbekun C.C (2008). The effect of coconut meal and coconut oil poultry, rations on the performance of laying?? Poult. Sci. 51:1132

[2]. Aremu, M.O. Olaore O., and Akintayo T.E (2006) A comprehensive study on the chemical and amino acid composition of some underutilized legumes flour. Park 1 nutria 9-34-38

[3]. Ashaye, O.A, Babalola S.O, Babalola A.O, Aina J.O and fasoyiro S.B. (2005). Chemical and organnoleptic characterization of pawpaw and Guava. World J. Agric. Sci iciJi 50-51.

[4]. Burubai, W., Amula, E., Daworiye P., Suowarri, T and nimame, P., (2009). Proximate composition and some technological properties of monodora myristical seeds. Electronic Journal of Environment Agriculture and food chemistry 8 (5):396-402

[5]. FAO/WHO (1991). Protein qulity evaluation report of joint FAO/WHO. Expert consultant FAO/WHO, Rome pp:19-21 
[6]. Idouraine A.Kohlhepp E.A., Weber C.W.., \& Martinez T.J., (1996) Nutrient constituents from eight lines of naked Squash (Cucurbita pepo L.J. Agric food chemi 44 (3): 721-724

[7]. Nzikou .J.M., Matos L.,Bouanga-kalou, G., Ndangui, C.B pambou.

[8]. Tobi N.P.G., Kimboguila. A., Siloa, Th Linder, M and Desobry, S.O (2009) Chemical composition on the seeds and oil Seeding idicum L. grown in Congo Brazzaville Advanced journal of Food Science and Technology (1):6-11

[9]. Odoemelum S.A 2005. Proximate composition and selected physicochemical properties of the seeds of Pentaclethra marcrophylla. Pakistan Journal of Nutrition 4(6):382-383.

[10]. Oyeleke, G.O (2009). Proximate, Minerals and ascorbic acid contents of two underutilized leguminous plant seed flour. (Piliostigma thonningi and Caesaplhima). Pulchernama Search light Vol3No2,pg 25-32 Indourasssine et al., 190 